\title{
Polymorphisms of SORBS1 Gene and Their Correlation with Milk Fat Traits of Cattleyak
}

\author{
Luyu Yang ${ }^{1,2}$, Xingyu Min ${ }^{1}$, Yanjin Zhu ${ }^{1}$, Yulei Hu ${ }^{1}$, Manzhen Yang ${ }^{2}$, Hailing $\mathrm{Yu}^{2}$, Jian Li ${ }^{1,2}$ \\ and Xianrong Xiong ${ }^{1,2, *}$ \\ 1 Key Laboratory of Qinghai-Tibetan Plateau Animal Genetic Reservation and Exploitation of Ministry of \\ Education, Southwest Minzu University, Chengdu 610041, China; yangluyu0413@yeah.net (L.Y.); \\ minxingyu2333@163.com (X.M.); zhuyj199434@163.com (Y.Z.); stonetear@163.com (Y.H.); \\ jianli_1967@163.com (J.L.) \\ 2 Key Laboratory of Animal Science of National Ethnic Affairs Commission, Southwest Minzu University, \\ Chengdu 610041, China; yangmanzhen2021@163.com (M.Y.); HaiLingYu96@163.com (H.Y.) \\ * Correspondence: xiongxianrong@163.com
}

check for updates

Citation: Yang, L.; Min, X.; Zhu, Y.; Hu, Y.; Yang, M.; Yu, H.; Li, J.; Xiong, X. Polymorphisms of SORBS1 Gene and Their Correlation with Milk Fat Traits of Cattleyak. Animals 2021, 11, 3461. https://doi.org/10.3390/ ani11123461

Academic Editor: Maria Luisa Dettori

Received: 1 November 2021

Accepted: 3 December 2021

Published: 5 December 2021

Publisher's Note: MDPI stays neutral with regard to jurisdictional claims in published maps and institutional affiliations.

Copyright: (c) 2021 by the authors. Licensee MDPI, Basel, Switzerland. This article is an open access article distributed under the terms and conditions of the Creative Commons Attribution (CC BY) license (https:/ / creativecommons.org/licenses/by/ $4.0 /)$.
Simple Summary: Increasing milk fat rate has a good effect on the milk quality of cattleyak. SNPs can help us find potential molecular markers for the milk fat traits of cattleyak, and they can be screened according to molecular markers when they are young. It provides a reference for cultivating high milk fat cattle population in the future. The results of this study suggest that the SORBS1 gene polymorphism is closely related to the milk fat traits of cattleyak, which could be used as a candidate genetic marker for milk fat trait selection in cattleyak. This study provides a new molecular marker and theoretical basis for screening the milk fat traits of cattleyak. It has a certain reference value for the research and improvement of milk quality.

Abstract: This study aimed to find the SNPs in the SORBS1 gene of cattleyak, analyze the relationship between its polymorphisms and the milk fat traits, and find potential molecular markers for the milk fat traits of cattleyak. The polymorphism of the SORBS1 gene in 350 cattleyak from Hongyuan County (Sichuan, China) were detected by PCR and DNA sequencing, and the correlation between these SNPs and the milk production traits of cattleyak was analyzed. The results showed that there were nine SNPs in the CDS and their adjacent non-coding regions of the SORBS1 gene, and all SNPs have three genotypes. The correlation analysis found that the genotypes with superior milk fat traits in the other eight alleles were homozygous genotypes with a high genotype frequency except the g.96284 G > A (c.3090 G > A) $(p<0.05)$. However, at locus g.96284 G > A, the milk fat percentage, monounsaturated fatty acids (MUFAs), polyunsaturated fatty acids (PUFAs) and saturated fatty acids (SFAs) of the GA genotype were significantly higher than that of GG and AA genotypes $(p<0.05)$. Among these SNPs, three SNPs (g.6256 C > T (c.298 C > T), g.24791 A > G (c.706 A > G) and g.29121 A > G (c.979 A > G)) caused the amino acids change. The genotypes of the three SNPs consist of three haplotypes and four diplotypes. The amino acid mutation degree of diplotype H1-H1 (CCAAAA) was the highest, and its milk fat percentage, MUFAs, PUFAs and SFAs were also the highest $(p<0.05)$. Taken together, we found nine SNPs in the SORBS1 gene that are closely related to the milk fat traits of cattleyak. Moreover, the mutation of amino acids caused by SNPs had positive effects on the milk fat traits of cattleyak. H1-H1 is the dominant diplotype which significantly related to the milk fat traits of cattleyak. This study provides a new molecular marker and theoretical basis for screening the milk fat traits of cattleyak.

Keywords: SORBS1 gene; cattleyak; milk fat traits; SNPs; diplotype

\section{Introduction}

Yak (Bos grunniens), a wild bovine species that lives $3500 \mathrm{~m}$ above sea level, is an iconic symbol of the Qinghai-Tibetan Plateau region and the nearby areas. Moreover, yak raising 
has become the main livelihood in the local area. However, the reproductive efficiency and production performance of yak are low, which cannot satisfy the local herdsman needs and industrial development [1]. As the hybrid offspring of yak (\$) and cattle (Bos taurus) $\left(\sigma^{\top}\right)$, the female cattleyak has obvious heterosis compared to yak, especially in its lactation performance [2,3]. Dairy products made from fermented and processed milk are popular with local herdsmen and tourists. As the main energy substance in milk, milk fat only accounts for $3 \sim 5 \%$ of the milk content, but it determines the nutritional value of milk $[4,5]$. Therefore, it is greatly meaningful to increase the percentage of milk fat and improve the composition of fatty acids in cattleyak.

The relevance between polymorphism and milk quality has been widely applied to the breeding of lactation traits, and the relationship between milk composition and genetic variation in milk production has a far-reaching impact on milk production [6-12]. In genetics, milk fatty acids have been found to be heritable, and the heritability was estimated at 0.22 to 0.71 [13]. In the past few years, with the rapid development of biotechnology, the mapping of candidate genes and quantitative trait locus (QTL) has been gradually applied to analyze lactation traits and breeding. Therefore, some promising SNPs have been shown to be significantly associated with lactation and its milk components [14-16].

The sorbin and SH3 domain-containing 1 (SORBS1) gene is a member of the SORBS family, and it encodes a Cbl-associated protein (CAP) that plays key roles in the signaling and stimulation of insulin [17-19]. Previous studies found that after a postprandial lipid (PPL) challenge, fatty acids and sterols related to cholesterol absorption were increased, while sterols related to cholesterol synthesis were decreased, and they detected that two SNPs (rs.12247017 and rs.12240292) in the SORBS1 gene were correlated with b-Sitosterol after correcting for multiple testing [20]. In addition, SORBS1 blocks the insulin stimulation of glucose transport in 3T3-L1 adipocytes [21]. The T228A polymorphism of SORBS1 is correlated with obesity and diabetes [22]. Recently, it was found that the SORBS1 gene has an effect on cell proliferation and migration, which can inhibit tumor metastasis and improve the sensitivity of tumors to chemotherapeutic drugs [23]. Above all, SORBS1 has multiple functions, but there are still many potential mechanisms that need to be studied.

A genome-wide association study revealed that the SORBS1 gene was one of 20 new candidate genes that were closely related to milk fat traits in Chinese Holstein cows [24]. However, there are few studies on the breeding of the milk fat traits of cattleyak, and there is no report on the association between cattleyak and the SORBS1 gene. Therefore, whether the SORBS1 gene is related to the creamy traits of cattleyak remains to be determined. The cattleyak is the subject of this experiment, the detected SNPs of the SORBS1 gene and its association with cattleyak milk fat traits was analyzed, and we looked for the molecular markers for the assisted selection of the milk fat traits of cattleyak.

\section{Materials and Methods}

\subsection{Animal and Preparation}

The study samples and data were collected in Ngawa Tibetan and Qiang Autonomous Prefecture Hongyuan County, Sichuan Province, China (longitudinal $32^{\circ} 78^{\prime} \mathrm{N}$ to $32^{\circ} 82^{\prime} \mathrm{N}$, latitudinal $102^{\circ} 52^{\prime} \mathrm{E}$ to $102^{\circ} 55^{\prime} \mathrm{E}$ ). In total, 350 female cattleyak (Jersey cattle $o^{\prime} \times$ yak ${ }^{\prime}$ ) were selected in this experiment. The female parent of our cattleyak comes from a group of relatively closed and natural mating yak, while the male parent comes from the frozen semen of the same batch of Jersey cattle. All animals were collected from August, and they have the same parity and lactation, a similar growth environment and equivalent nutritional conditions. The $25 \mathrm{~mL}$ milk samples of each cattleyak were collected and sent to the Hongya Yangping branch of New Hope Co., Ltd. The physical and chemical indexes (DHI) of each sample were analyzed by a milk composition analyzer. The $10 \mathrm{~mL}$ blood samples were collected from the jugular vein of each cattleyak by using a sterile blood collection device, and then put into the $4{ }^{\circ} \mathrm{C}$ ice box. All blood samples were taken back to the laboratory and placed in a freezer at $-20^{\circ} \mathrm{C}$. 


\subsection{DNA Extraction from Blood}

The DNA was extracted from whole-blood samples using the Blood Genomic DNA Extraction Kit (Solarbio, Beijing, China). The purity and concentration of the DNA were detected by a nucleic acid concentration detector, and the integrity of the DNA was then detected by agarose gel electrophoresis.

\subsection{Primer Design and Sequencing}

The standard sequence is from NCBI, which has 31 exons and 31 introns (Accession Number: NW_005394038.1). Based on the DNA sequence, 12 pairs of primers were designed for the PCR amplification of the SORBS1 gene CDS and their adjacent regions (Table 1). The PCR reaction was $25 \mu \mathrm{L}: 12.5 \mu \mathrm{L} 2 \times$ Rapid Taq Master Mix, $1 \mu \mathrm{L}$ upstream and $1 \mu \mathrm{L}$ downstream primers, $1 \mu \mathrm{L}$ DNA template and add ddH2O to $25 \mu \mathrm{L}$. PCR reaction conditions were as follows: denaturation for $3 \mathrm{~min}$ at $95^{\circ} \mathrm{C}, 35$ cycles for $15 \mathrm{~s}$ at $95{ }^{\circ} \mathrm{C}$, annealing temperature for $15 \mathrm{~s}$ and $72{ }^{\circ} \mathrm{C}$ for $15 \mathrm{~s}$, and extension at $72{ }^{\circ} \mathrm{C}$ for $5 \mathrm{~min}$. PCR products were detected by $2 \%$ agarose gel electrophoresis, and sent to Tsingke Biotechnology Co., Ltd. for sequencing.

Table 1. Conventional PCR amplification primers for CDS and their adjacent regions of the SORBS1 gene.

\begin{tabular}{|c|c|c|c|c|}
\hline Primer Name & Sequence $\left(5^{\prime}-3^{\prime}\right)$ & $\begin{array}{l}\text { PCR Product } \\
\text { Size (bp) }\end{array}$ & Region (bp) & $\begin{array}{c}\text { Annealing } \\
\text { Temperature }\left({ }^{\circ} \mathrm{C}\right)\end{array}$ \\
\hline Primer 1 & $\begin{array}{l}\text { F: CACTTGCTCTCCССТTCCTG } \\
\text { R: CAACGTTCAGCCTCTGGACT }\end{array}$ & 675 & $5791-6750$ & 62 \\
\hline Primer 2 & $\begin{array}{l}\text { F: ATGCCCTGTGCTGTCAACTT } \\
\text { R: TACAGTGGTCGCTGCCATAC }\end{array}$ & 642 & $7741-8740$ & 60 \\
\hline Primer 3 & $\begin{array}{l}\text { F: GGACAGGAGAGTTCTGTGGC } \\
\text { R: AAGGACAGAGCTGCTGGAAC }\end{array}$ & 939 & $18,181-19,180$ & 63 \\
\hline Primer 4 & $\begin{array}{l}\text { F: AGAGTGCCTCACTGCATGTC } \\
\text { R: ACAGACTGGTGAACAGCCAC }\end{array}$ & 684 & $24,361-25,360$ & 59 \\
\hline Primer 5 & $\begin{array}{l}\text { F: ACCGGATTGAGCCACAGTTT } \\
\text { R: GGCACCAAGATTTTCCCAGC }\end{array}$ & 789 & $28,681-29,680$ & 60 \\
\hline Primer 6 & $\begin{array}{l}\text { F: ACTGAGGTCTCTCAGCCAGT } \\
\text { R: TACAGTGGTCGCTGCCATAC }\end{array}$ & 950 & $43,111-44,110$ & 59 \\
\hline Primer 7 & $\begin{array}{l}\text { F: CTGTCTGACCCTGCTCTGTG } \\
\text { R: GCCGGTGAGAAACTCAGGAA }\end{array}$ & 680 & $79,641-80,640$ & 61 \\
\hline Primer 8 & $\begin{array}{l}\text { F: TGCCATCTCCTCCСТACACA } \\
\text { R: GTCCACACCATGGCCACTAA }\end{array}$ & 721 & $85,681-86,680$ & 61 \\
\hline Primer 9 & $\begin{array}{l}\text { F: CCAAGATGAGCACGGAAGGT } \\
\text { R: GGGATTGTGGTGGTACCCAG }\end{array}$ & 649 & $94,081-95,080$ & 61 \\
\hline Primer 10 & $\begin{array}{l}\text { F: TCTCCAGACATCCCGTGTGA } \\
\text { R: GGTCTTGTGGGCATCCACTT }\end{array}$ & 952 & $96,061-97,060$ & 61 \\
\hline Primer 11 & $\begin{array}{l}\text { F: GTTGAACGGATCTCCCCCAA } \\
\text { R: GCAACTGGAAACTGCCСTTC }\end{array}$ & 530 & $112,141-113,140$ & 63 \\
\hline Primer 12 & $\begin{array}{l}\text { F: AAGCCCCTAACCTTGGTGTG } \\
\text { R: AGAGCACGTGCAGGCTAAAT }\end{array}$ & 790 & $114,001-115,000$ & 61 \\
\hline
\end{tabular}

Abbreviations: $\mathrm{F}=$ Forward primer; $\mathrm{R}=$ Reverse primer.

\subsection{Genotyping and Statistical Analysis}

Based on the sequencing results, Chromas 2 software was used to analyze and find SNP sites. Using Excel 2019 to calculate the genotype frequency and allele frequency, the polymorphic information content (PIC) was calculated with different genotype frequency and allele frequency. The formula is as follows:

$$
P I C=1-H_{0}-\sum_{i=1}^{n-1} \sum_{j-i+1}^{n} 2 P i^{2} P j^{2}
$$


$P i$ and $P j$ are the frequencies of the $i$ and $j$ alleles, and $n$ is the number of alleles. The Standard Amino acid sequence was derived from NCBI and compared with the pre- and post-mutation amino acid sequence in BLAST to test if the SNPs changed the amino acid sequence. Haploview 4.2 software was used to analyze the haplotype. The effect of different genotypes and diplotypes on the milk fat traits of cattleyak was analyzed by the Analyze-General linear model univariate in SPSS 19.0 software. The formula is as follows:

$$
Y_{i}=\mu+G_{i}+e
$$

Among them, $Y_{i}$ is the phenotypic value of milk fat traits, and $\mu$ is the population mean of milk fat traits, $G_{i}$ is the total effect and $e$ is the random residual effect. Differences were considered significant at $p<0.05$.

\section{Results}

\subsection{PCR Amplification and SNP Screening}

The concentration and purity of genomic DNA in cattleyak blood were detected by a nucleic acid concentration detector, and the samples were all qualified. Using $2 \%$ agarose gel electrophoresis to detect four amplified products, clear and single-purpose bands were obtained. The specificity is good and can be used for subsequent sequencing analysis (Figure 1).

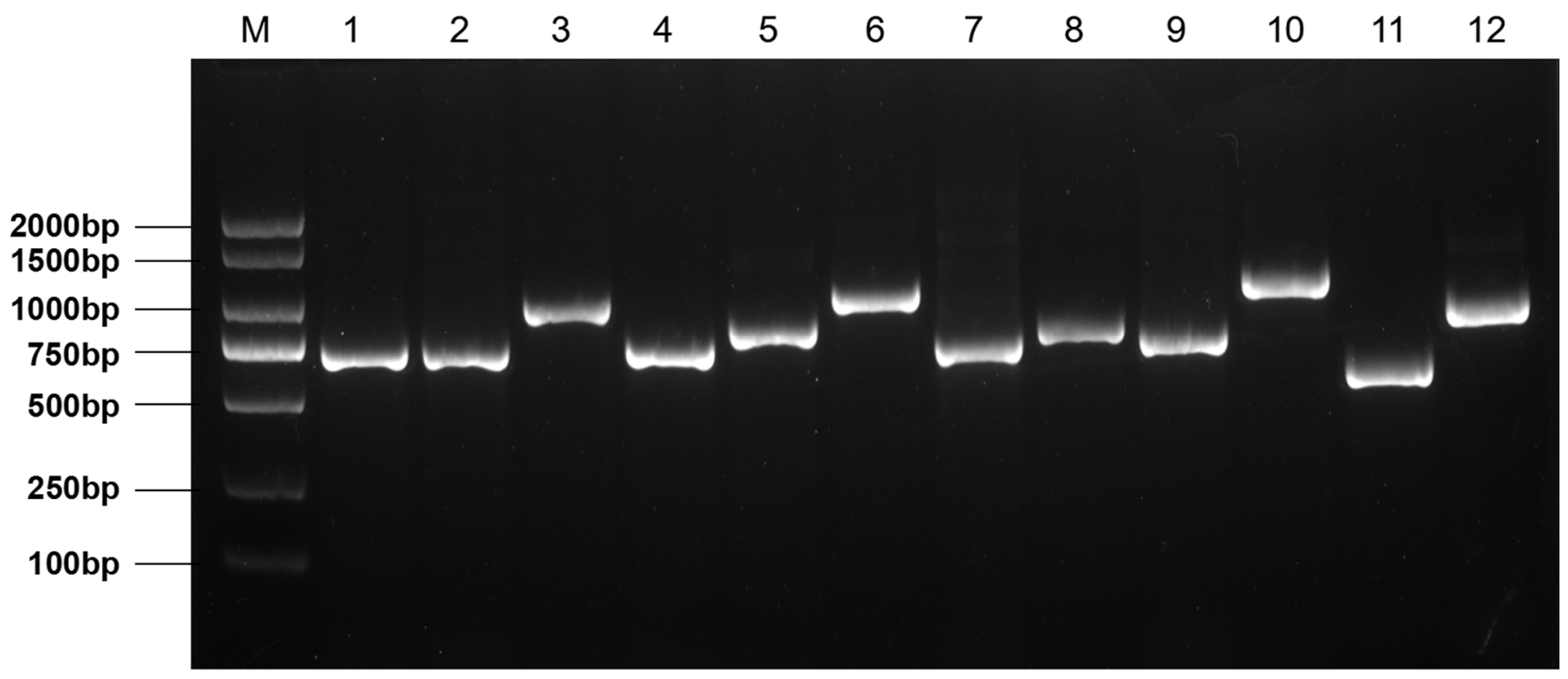

Figure 1. PCR amplification products (12 pairs of primers) for CDS and their adjacent regions of the SORBS1 gene.

A total of nine SNPs in the CDS and their adjacent regions of the SORBS1 gene were detected in the cattleyak population by PCR and sequencing (Figure 2). g.6256 C > T (c.298 $\mathrm{C}>\mathrm{T}$ ) and g.24791 G > A (c.706 A > G) were detected by primer 1 and primer 4 PCR product, g.29029 C > T, g.29050 A > G, g.29121 A > G (c.979 A > G), g.29245 T > C, g.29305 $\mathrm{T}>\mathrm{C}$ and g.29347 T > C were detected by primer 5 PCR product, g.96284 G > A (c.3090 G > A) was detected by primer 10 PCR product. Additionally, four SNPs (g.6256 C > T, g.24791 G > A, g.29121 A > G and g.96284 G > A) are located in the CDS region, while the other five SNPs are located in the intron region adjacent of the SORBS1 gene. 
Animals 2021, 11, 3461

5 of 11

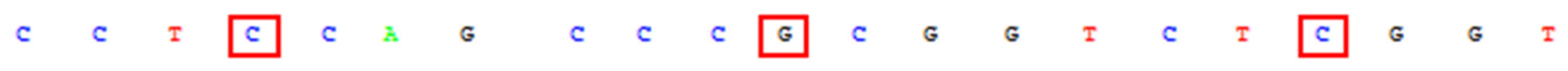

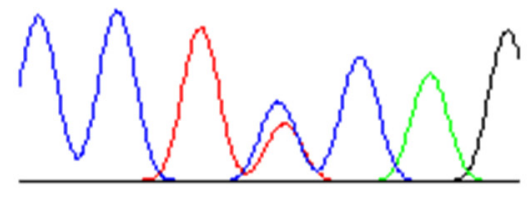

A. g.6256 C>T (c.298 C>T)

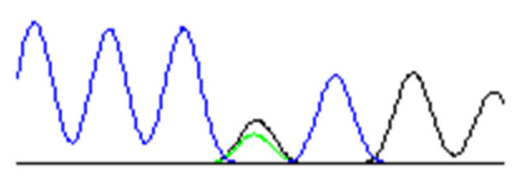

B. g.24791 $A>G$ (c.706 $A>G$ )

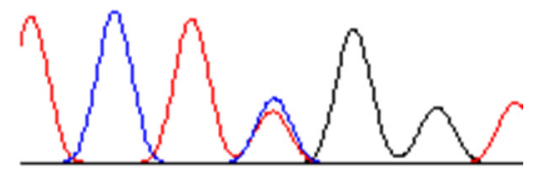

C. g.29029 T>C

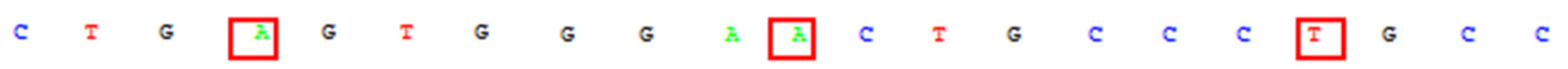

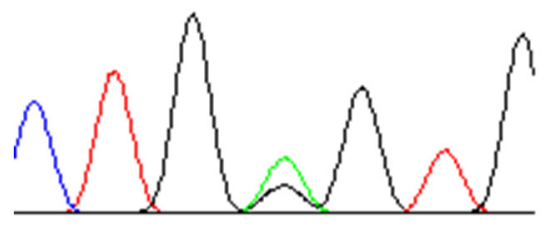

D. g.29050 A $>\mathrm{G}$

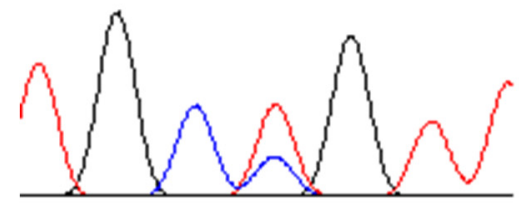

G. g.29305 C>T

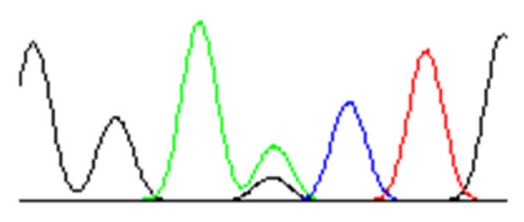

E. g.29121 $A>G$ (c.979 A>G)
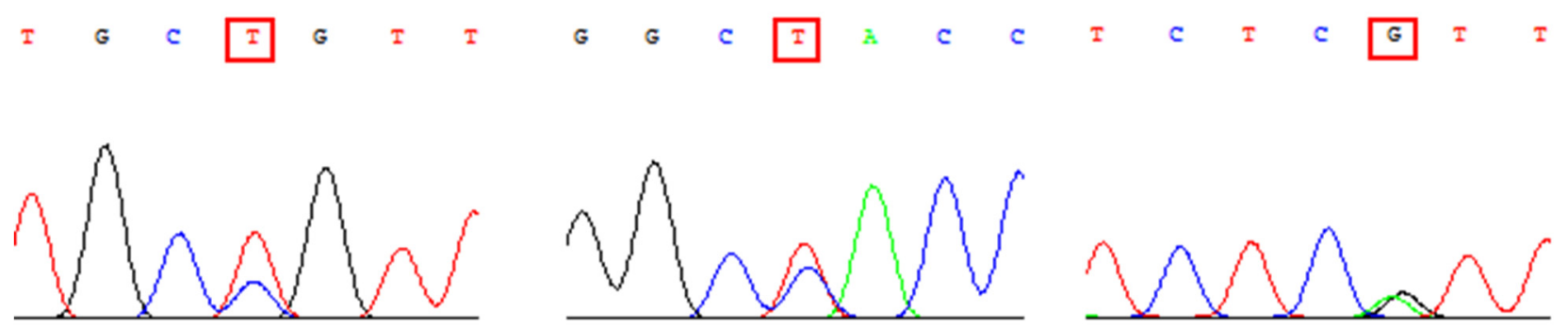

H. g.29347 T>C

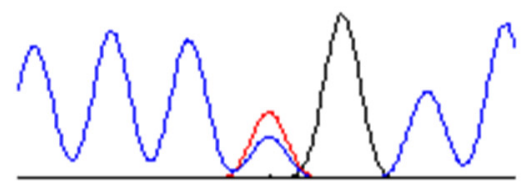

F. g.29245 C>T

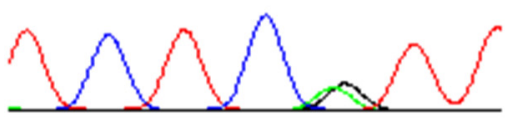

l. g. $96284 \mathrm{G}>\mathrm{A}$ (c.3090 G>A)

Figure 2. Sequencing diagram of heterozygous genotypes in the SNP loci of the SORBS1 gene (red box marker). Four SNPs $(\mathbf{A}, \mathbf{B}, \mathbf{E}, \mathbf{I})$ are located in the CDS region of the SORBS1 gene, c. system naming indicates the position of the site on the eDNA sequence. Five SNPs $(\mathbf{C}, \mathbf{D}, \mathbf{F}, \mathbf{G}, \mathbf{H})$ are located in the intro region adjacent to the CDS region of the SORBS1 gene.

3.2. SNP Genotyping of the SORBS1 Gene

The genotype frequency, allele frequency and polymorphic information content of the nine SNP loci were shown in Table 2. The results showed that all the nine SNP loci had three genotypes in the cattleya population. The PIC of g.6256 C > T, g.24791 G > A, g.29029 C > T and g.29050 A > G were 0.361, g.29121 A > G was 0.346, g.29245 T > C, g.29305 $\mathrm{T}>\mathrm{C}$, g.29347 T > C and g.96284 G > A were 0.358. The PIC of all SAPs was between $0.25 \sim 0.5$, and all of them were moderately polymorphic. All the other SAPs conformed to the Hardy-Weinberg balance except g.29121 A > G site $(p>0.05)$. 
Table 2. SNP analysis of the population genetic parameters of SORBS1.

\begin{tabular}{|c|c|c|c|c|c|c|c|c|c|c|c|}
\hline Loci & $\begin{array}{c}\text { Genomic } \\
\text { Region }\end{array}$ & $\begin{array}{l}\text { Amino } \\
\text { Acid }\end{array}$ & Genotype & $\begin{array}{c}\text { Genotype } \\
\text { Frequency } \\
\quad(\%)\end{array}$ & Allele & $\begin{array}{c}\text { Allele } \\
\text { Frequency } \\
(\%)\end{array}$ & Ho & $\mathrm{He}$ & $\mathrm{Ne}$ & PIC & $p$ Value \\
\hline \multirow{2}{*}{$\begin{array}{l}\text { g. } 6256 \text { C > T } \\
\text { (c. } 298 \text { C > T) }\end{array}$} & Exon 3 & Ser100Pro & $\mathrm{CC}$ & 38.3 & $\mathrm{C}$ & 61.9 & 0.528 & 0.472 & 1.894 & 0.361 & 0.054 \\
\hline & & & $\begin{array}{l}\text { CT } \\
\text { TT }\end{array}$ & $\begin{array}{l}47.1 \\
14.6\end{array}$ & $\mathrm{~T}$ & 38.1 & & & & & \\
\hline \multirow{2}{*}{$\begin{array}{c}\text { g. } 24791 \mathrm{~A}>\mathrm{G} \\
\text { (c.706 A > G) }\end{array}$} & Exon 7 & Arg229His & AA & 38.3 & A & 61.9 & 0.528 & 0.472 & 1.894 & 0.361 & 0.054 \\
\hline & & & $\begin{array}{l}\text { AG } \\
\text { GG }\end{array}$ & $\begin{array}{l}47.1 \\
14.6\end{array}$ & G & 38.1 & & & & & \\
\hline g.29029 T > C & Intron 7 & - & $\begin{array}{l}\text { TT } \\
\text { TC } \\
\text { CC }\end{array}$ & $\begin{array}{l}38.3 \\
47.1 \\
14.6\end{array}$ & $\begin{array}{l}\mathrm{T} \\
\mathrm{C}\end{array}$ & $\begin{array}{l}61.9 \\
38.1\end{array}$ & 0.528 & 0.472 & 1.894 & 0.361 & 0.054 \\
\hline g. $29050 \mathrm{~A}>\mathrm{G}$ & Intron 7 & - & $\begin{array}{l}\text { AA } \\
\text { AG } \\
\text { GG }\end{array}$ & $\begin{array}{l}38.3 \\
47.1 \\
14.6\end{array}$ & $\begin{array}{l}A \\
G\end{array}$ & $\begin{array}{l}61.9 \\
38.1\end{array}$ & 0.528 & 0.472 & 1.894 & 0.361 & 0.054 \\
\hline \multirow[t]{2}{*}{$\begin{array}{l}\text { g. } 29121 \mathrm{~A}>\mathrm{G} \\
\text { (c. } 979 \mathrm{~A}>\mathrm{G} \text { ) }\end{array}$} & Exon 8 & Ala327Thr & $\mathrm{AA}$ & 48.0 & A & 66.7 & 0.556 & 0.444 & 1.799 & 0.346 & 0.017 \\
\hline & & & $\begin{array}{l}\text { AG } \\
\text { GG }\end{array}$ & $\begin{array}{l}37.4 \\
14.6\end{array}$ & G & 33.3 & & & & & \\
\hline g. 29245 C > T & Intron 8 & - & $\begin{array}{l}\text { CC } \\
\text { CT } \\
\text { TT }\end{array}$ & $\begin{array}{l}40.6 \\
44.8 \\
14.6\end{array}$ & $\begin{array}{l}\mathrm{C} \\
\mathrm{T}\end{array}$ & $\begin{array}{l}63.0 \\
37.0\end{array}$ & 0.534 & 0.466 & 1.873 & 0.358 & 0.073 \\
\hline g. $29305 \mathrm{C}>\mathrm{T}$ & Intron 8 & - & $\begin{array}{l}\text { CC } \\
\text { CT } \\
\text { TT }\end{array}$ & $\begin{array}{l}40.6 \\
44.8 \\
14.6\end{array}$ & $\begin{array}{l}\mathrm{C} \\
\mathrm{T}\end{array}$ & $\begin{array}{l}63.0 \\
37.0\end{array}$ & 0.534 & 0.466 & 1.873 & 0.358 & 0.073 \\
\hline g.29347 T > C & Intron 8 & - & $\begin{array}{l}\text { TT } \\
\text { TC } \\
\text { CC }\end{array}$ & $\begin{array}{l}40.6 \\
44.8 \\
14.6\end{array}$ & $\begin{array}{l}\mathrm{T} \\
\mathrm{C}\end{array}$ & $\begin{array}{l}63.0 \\
37.0\end{array}$ & 0.534 & 0.466 & 1.873 & 0.358 & 0.073 \\
\hline \multirow[t]{2}{*}{$\begin{array}{l}\text { g. } 96284 \mathrm{G}>\mathrm{A} \\
(\text { c. } 3090 \mathrm{G}>\mathrm{A})\end{array}$} & Exon 28 & Ser1030Ser & GG & 39.7 & G & 62.7 & 0.532 & 0.468 & 1.879 & 0.358 & 0.057 \\
\hline & & & $\begin{array}{l}\text { GA } \\
\text { AA }\end{array}$ & $\begin{array}{l}46.0 \\
14.3\end{array}$ & A & 37.3 & & & & & \\
\hline
\end{tabular}

Abbreviations: Ho = Homozygosity; He = Heterozygosity; Ne = Effective number of alleles; PIC = Polymorphic information content. $p>0.05$ suggested that the population gene is in Hardy-Weinberg balance and the sample comes from the same mendel population.

\subsection{Haplotype and Diplotype Analysis of Each Amino Acid Mutation Site of SORBS1}

During the comparison of the amino acid residue sequence alignment of the SORBS1 gene before and after mutation, we found that three SNPs (g.6256 C > T, g.24791 A > G and g.29121 A > G) caused amino acid changes among the four SNPs located in the CDS region. Moreover, no amino acid changes were observed at g.96284 G > A. The three mutations were Ser100Pro, Arg229His and Ala327Thr (Table 2). Using the three SNPs, a haplotype analysis was carried out using Haploview software (Table 3). The haplotype analysis showed that the three haplotypes were in fact found in the population of cattleyak, of which H1 (C-A-A) and H2 (T-G-G) were the major haplotypes, accounting for $61.9 \%$ and $33.3 \%$, respectively. The frequency of H3 (T-G-A) was $4.9 \%$. Based on these three haplotypes, we further obtained four combinations, in the form of H1-H1 (CCAAAA), H1-H2 (CTAGAG), H1-H3 (CTAGAA) and H2-H2 (TTGGGG) (Figure 3), of which H1-H1 (38.3\%) and $\mathrm{H} 2-\mathrm{H} 2$ (37.4\%) belonged to dominant diplotypes.

Table 3. Haplotype and haplotype frequencies of the three mutations in the SORBS1 gene.

\begin{tabular}{ccccc}
\hline \multirow{2}{*}{ Haplotype } & \multicolumn{2}{c}{ Ploymorphism Sites of SORBS1 Gene } & \\
\cline { 2 - 4 } & $\begin{array}{c}\text { g.6256 C > T } \\
(\text { c.298 C > T) }\end{array}$ & $\begin{array}{c}\text { g.24791 A > G } \\
(\text { c.706 A > G) }\end{array}$ & $\begin{array}{c}\text { g.29121 A > G } \\
\text { (c.979 A > G) }\end{array}$ & Frequency (\%) \\
\hline H1 & $\mathrm{C}$ & $\mathrm{A}$ & $\mathrm{A}$ & 61.8 \\
H2 & $\mathrm{T}$ & $\mathrm{G}$ & $\mathrm{G}$ & 33.3 \\
H3 & $\mathrm{T}$ & $\mathrm{G}$ & $\mathrm{A}$ & 4.9 \\
\hline
\end{tabular}




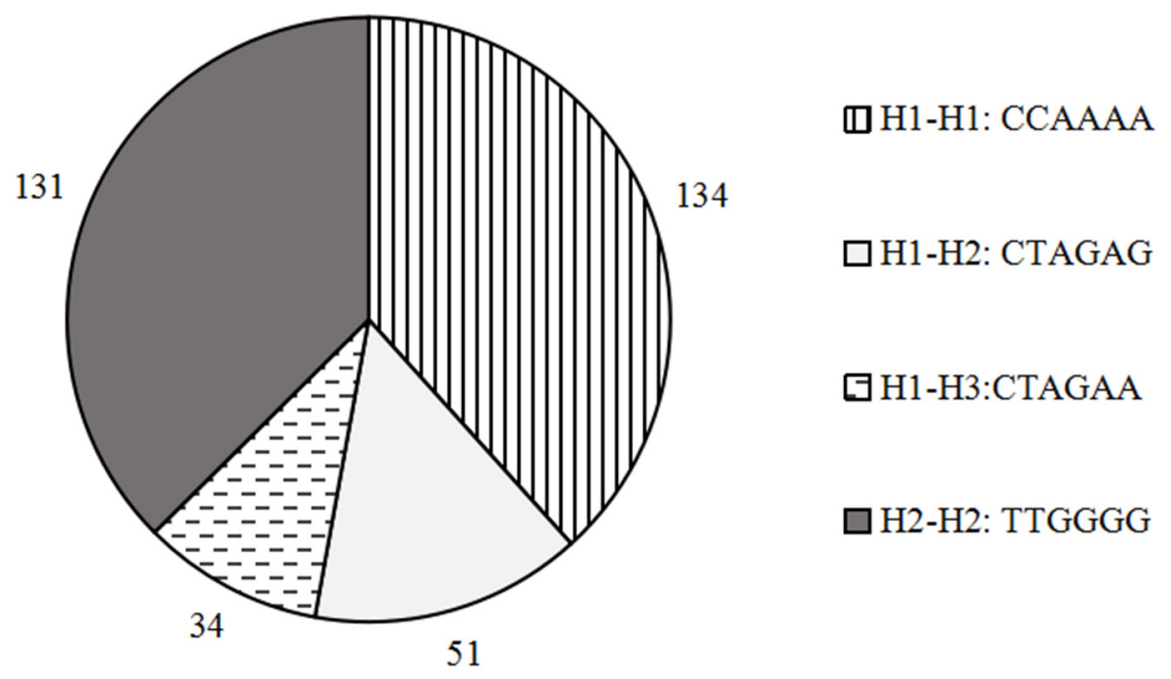

Figure 3. Diplotypes and frequencies of the three mutations in the SORBS1 gene.

\subsection{Association Analysis between SNP Genotypes and Milk Fat Traits}

Based on the data of the SNP genotyping, the correlation analysis of a single locus with the milk fat percentage and fatty acids of cattleyak was carried out. As shown in Table 4, in terms of milk fat percentage and fatty acid content, most of the homozygous (CC genotype at g.6256 C > T, AA genotype at g.24791 A > G, TT genotype at g.29029 T > C, AA genotype at g.29050 A > G, AA genotype at g.29121 A > G, CC genotype at g.29245 C > T, CC genotype at g.29305 C > T, TT genotype at g.29347 T > C and GA genotype at g.96284 $\mathrm{G}>\mathrm{A})$ were significantly higher than the other genotypes $(p<0.05)$. At locus g.96284 $\mathrm{G}>\mathrm{A}$, the milk fat percentage, monounsaturated fatty acids (MUFAs), polyunsaturated fatty acids (PUFAs) and saturated fatty acids (SFAs) of the GA genotype were significantly higher than that in GG and AA genotypes $(p<0.05)$.

Table 4. Association analysis between genotypes and the milk fat of cattleyak.

\begin{tabular}{|c|c|c|c|c|c|}
\hline Loci & Genotype & Milk Fat Percentage (\%) & MUFAs & PUFAs & SFAs \\
\hline \multirow[t]{3}{*}{ g. $6256 \mathrm{C}>\mathrm{T}$} & $\mathrm{CC}$ & $5.649 \pm 0.499^{a}$ & $1.605 \pm 0.212^{\mathrm{a}}$ & $0.180 \pm 0.018^{a}$ & $3.771 \pm 0.388^{a}$ \\
\hline & $\mathrm{CT}$ & $4.783 \pm 0.732^{b}$ & $1.305 \pm 0.177^{b}$ & $0.162 \pm 0.023^{b}$ & $3.268 \pm 0.479^{b}$ \\
\hline & TT & $3.280 \pm 0.677^{c}$ & $1.033 \pm 0.231^{\mathrm{c}}$ & $0.130 \pm 0.011^{c}$ & $1.834 \pm 0.529^{c}$ \\
\hline \multirow{3}{*}{ g.24791 A > G } & AA & $5.649 \pm 0.499^{\mathrm{a}}$ & $1.605 \pm 0.212^{\mathrm{a}}$ & $0.180 \pm 0.018^{\mathrm{a}}$ & $3.771 \pm 0.388^{a}$ \\
\hline & AG & $4.783 \pm 0.732^{b}$ & $1.305 \pm 0.177^{b}$ & $0.162 \pm 0.023^{b}$ & $3.268 \pm 0.479^{b}$ \\
\hline & GG & $3.280 \pm 0.677^{c}$ & $1.033 \pm 0.231^{\mathrm{c}}$ & $0.130 \pm 0.011^{\mathrm{c}}$ & $1.834 \pm 0.529^{c}$ \\
\hline \multirow[t]{3}{*}{ g.29029 T > C } & $\mathrm{TT}$ & $5.649 \pm 0.499^{a}$ & $1.605 \pm 0.212^{\mathrm{a}}$ & $0.180 \pm 0.018^{\mathrm{a}}$ & $3.771 \pm 0.388^{a}$ \\
\hline & $\mathrm{TC}$ & $4.783 \pm 0.732^{b}$ & $1.305 \pm 0.177^{b}$ & $0.162 \pm 0.023^{b}$ & $3.268 \pm 0.479^{b}$ \\
\hline & $\mathrm{CC}$ & $3.280 \pm 0.677^{c}$ & $1.033 \pm 0.231^{\mathrm{c}}$ & $0.130 \pm 0.011^{c}$ & $1.834 \pm 0.529^{c}$ \\
\hline \multirow[t]{3}{*}{ g.29050 A > G } & AA & $5.649 \pm 0.499^{a}$ & $1.605 \pm 0.212^{\mathrm{a}}$ & $0.180 \pm 0.018^{\mathrm{a}}$ & $3.771 \pm 0.388^{a}$ \\
\hline & AG & $4.783 \pm 0.732^{b}$ & $1.305 \pm 0.177^{b}$ & $0.162 \pm 0.023^{b}$ & $3.268 \pm 0.479^{b}$ \\
\hline & GG & $3.280 \pm 0.677^{c}$ & $1.033 \pm 0.231^{c}$ & $0.130 \pm 0.011^{c}$ & $1.834 \pm 0.529^{c}$ \\
\hline \multirow[t]{3}{*}{ g.29121 A > G } & AA & $5.516 \pm 0.621^{\mathrm{a}}$ & $1.568 \pm 0.225^{\mathrm{a}}$ & $0.178 \pm 0.021^{\mathrm{a}}$ & $3.662 \pm 0.516^{a}$ \\
\hline & AG & $4.729 \pm 0.715^{b}$ & $1.274 \pm 0.152^{b}$ & $0.160 \pm 0.020^{b}$ & $3.278 \pm 0.401^{b}$ \\
\hline & GG & $3.280 \pm 0.677^{c}$ & $1.033 \pm 0.231^{c}$ & $0.130 \pm 0.011^{c}$ & $1.834 \pm 0.529^{c}$ \\
\hline \multirow[t]{3}{*}{ g. 29245 C > T } & $\mathrm{CC}$ & $5.611 \pm 0.588^{a}$ & $1.587 \pm 0.231^{\mathrm{a}}$ & $0.178 \pm 0.021^{a}$ & $3.746 \pm 0.465^{a}$ \\
\hline & $\mathrm{CT}$ & $4.773 \pm 0.696^{b}$ & $1.305 \pm 0.167^{b}$ & $0.163 \pm 0.022^{a}$ & $3.625 \pm 0.428^{b}$ \\
\hline & $\mathrm{TT}$ & $3.280 \pm 0.677^{c}$ & $1.033 \pm 0.231^{\mathrm{c}}$ & $0.130 \pm 0.011^{\mathrm{c}}$ & $1.834 \pm 0.529^{c}$ \\
\hline \multirow[t]{3}{*}{ g.29305 C > T } & $\mathrm{CC}$ & $5.611 \pm 0.588^{a}$ & $1.587 \pm 0.231^{\mathrm{a}}$ & $0.178 \pm 0.021^{\mathrm{a}}$ & $3.746 \pm 0.465^{a}$ \\
\hline & $\mathrm{CT}$ & $4.773 \pm 0.696^{b}$ & $1.305 \pm 0.167^{b}$ & $0.163 \pm 0.022^{\mathrm{a}}$ & $3.625 \pm 0.428^{b}$ \\
\hline & $\mathrm{TT}$ & $3.280 \pm 0.677^{c}$ & $1.033 \pm 0.231^{\mathrm{c}}$ & $0.130 \pm 0.011^{c}$ & $1.834 \pm 0.529^{c}$ \\
\hline
\end{tabular}


Table 4. Cont.

\begin{tabular}{cccccc}
\hline Loci & Genotype & Milk Fat Percentage (\%) & MUFAs & PUFAs & SFAs \\
\hline g.29347 T > C & TT & $5.611 \pm 0.588^{\mathrm{a}}$ & $1.587 \pm 0.231^{\mathrm{a}}$ & $0.178 \pm 0.021^{\mathrm{a}}$ & $3.746 \pm 0.465^{\mathrm{a}}$ \\
& TC & $4.773 \pm 0.696^{\mathrm{b}}$ & $1.305 \pm 0.167^{\mathrm{b}}$ & $0.163 \pm 0.022^{\mathrm{a}}$ & $3.625 \pm 0.428^{\mathrm{b}}$ \\
& CC & $3.280 \pm 0.677^{\mathrm{c}}$ & $1.033 \pm 0.231^{\mathrm{c}}$ & $0.130 \pm 0.011^{\mathrm{c}}$ & $1.834 \pm 0.529^{\mathrm{c}}$ \\
g.96284 G > A & GG & $4.335 \pm 0.772^{\mathrm{c}}$ & $1.297 \pm 0.377^{\mathrm{b}}$ & $0.152 \pm 0.029^{\mathrm{b}}$ & $2.829 \pm 0.679^{\mathrm{b}}$ \\
& GA & $5.334 \pm 0.612^{\mathrm{a}}$ & $1.483 \pm 0.167^{\mathrm{a}}$ & $0.174 \pm 0.021^{\mathrm{a}}$ & $3.565 \pm 0.467^{\mathrm{a}}$ \\
& AA & $5.040 \pm 0.283^{\mathrm{b}}$ & $1.278 \pm 0.088^{\mathrm{b}}$ & $0.168 \pm 0.011^{\mathrm{a}}$ & $3.417 \pm 0.024^{\mathrm{a}}$ \\
\hline
\end{tabular}

Abbreviations: MUFAs = Monounsaturated fatty acids; PUFAs = Polyunsaturated fatty acids; SFAs = Saturated fatty acids. ${ }^{\text {a-c }}$ Values within a row with different superscripts differ significantly at $p<0.05$.

\subsection{Association Analysis between Genotype Combinations and the Milk Fat Traits of Cattleyak}

The genotype combination of $\mathrm{H} 2-\mathrm{H} 2$ did not cause the change of amino acid. There is a possibility of amino acid variation in the part of the cattleyak whose genotype combinations are $\mathrm{H} 1-\mathrm{H} 2$ and $\mathrm{H} 1-\mathrm{H} 3$. The base mutation in the combination of $\mathrm{H} 1-\mathrm{H} 1$ resulted in the mutation of all three amino acids. The results of the ANOVA analysis showed that H1-H1 had the highest milk fat percentage, MUFAs, PUFAs and SFAs, while $\mathrm{H} 2-\mathrm{H} 2$ had the lowest milk fat percentage and fatty acid content (Table 5). The differences were statistically significant $(p<0.05)$.

Table 5. Association analysis of different genotype combinations of amino acid mutation sites with milk fat traits.

\begin{tabular}{ccccccc}
\hline Diplotype & $\begin{array}{c}\text { Combinatorial } \\
\text { Genotype }\end{array}$ & $\begin{array}{c}\text { Number of Amino } \\
\text { Acid Mutations }\end{array}$ & $\begin{array}{c}\text { Milk Fat } \\
\text { Percentage (\%) }\end{array}$ & MUFAs & PUFAs & SFAs \\
\hline H1-H1 & CCAAAA & 3 & $5.649 \pm 0.499^{\mathrm{a}}$ & $1.605 \pm 0.161^{\mathrm{a}}$ & $0.180 \pm 0.018^{\mathrm{a}}$ & $3.771 \pm 0.388^{\mathrm{a}}$ \\
H1-H2 & CTAGAG & $0-3$ & $4.783 \pm 0.595^{\mathrm{b}}$ & $1.305 \pm 0.143^{\mathrm{c}}$ & $0.162 \pm 0.020^{\mathrm{c}}$ & $3.268^{ \pm} \pm 0.396^{\mathrm{b}}$ \\
H1-H3 & CTAGAA & $1-3$ & $4.992 \pm 0.465^{\mathrm{b}}$ & $1.421 \pm 0.122^{\mathrm{b}}$ & $0.171 \pm 0.027^{\mathrm{b}}$ & $3.321 \pm 0.516^{\mathrm{b}}$ \\
H2-H2 & TTGGGG & 0 & $3.280 \pm 0.652^{\mathrm{c}}$ & $1.033 \pm 0.153^{\mathrm{d}}$ & $0.130 \pm 0.011^{\mathrm{d}}$ & $1.834 \pm 0.262^{\mathrm{c}}$ \\
\hline
\end{tabular}

Abbreviations: MUFAs = Monounsaturated fatty acids; PUFAs = Polyunsaturated fatty acids; SFAs = Saturated fatty acids. ${ }^{\text {a-d }}$ Values within a row with different superscripts differ significantly at $p<0.05$.

\section{Discussion}

Recently, the study of the polymorphism has been used to optimize the performance and composition of dairy cows [25-28]. The GWAS data in Li and his colleagues' study suggested that a SNP in the SORBS1 gene can significantly influence the composition of fatty acids in milk, especially MUFAs and PUFAs [24]. The fatty acids in milk have positive effects on human health. For example, previous study showed that MUFAs had a positive effect on human health due to their cholesterol-lowering properties [29]. PUFAs are essential nutrients which play the important role in plasma lipids and endothelial function. Additionally, PUFAs can be also used in the prevention and treatment of coronary heart disease [30]. Hereby, we detected the potential SNP in the SORBS1 gene of cattleyak, and we revealed the effect of the SNPs in the SORBS1 CDS and their adjacent non-coding regions on the milk fat traits of cattleyak.

In this study, a total of nine SNPs located in the CDS and their adjacent non-coding regions of the SORBS1 gene in cattleyak were detected. After genotyping, all nine SNPs were found that have three genotypes in the population of cattleyak, and the dominant genotypes were mainly heterozygotes. In addition, our results showed that the genetic richness was high and had the potential of genetic variation, which lead to a more abundant selection effect. The natural selection, artificial selection intervention, genetic drift and other factors could lead to changes in some animal nucleotides so that the biological genetic traits become more colorful [31]. The size of the population genetic variation represents the level of the population genetic richness. Generally speaking, the higher the population genetic variation is, the higher is the population genetic richness. Thus, the PIC is often used as an indicator [32,33]. With the exception of g.29121 A > G, the other eight SNPs have reached the Hardy-Weinberg balance, which suggested that these SNPs of cattleyak 
were not strongly selected and might not be influenced by mutation, selection and genetic drift. It is also possible that the alleles and genotypes have a genetic advantage in their adaptability that rebalanced after a long period of artificial selection and breeding [34]. However, g.29121 A > G was out of balance, which means that traces of the artificial selection can be found. Thus, the other eight alleles are more likely to be rebalanced after a long period of artificial selection and reproduction.

In a previous study, it was generally assumed that only SNPs in exons were associated with biological traits, and these SNPs in introns did not affect biological traits [35-37]. In this study, five SNPs (g.29029 T > C, g.29050 A > G, g.29245 C > T, g.29305 C > T and g.29347 T > C), located in the introns of the SORBS1 gene were found to be significantly associated with the cattleyak milk fat traits. A recent study found that introns were involved in the gene splicing in eukaryotes, and that the mutation of introns might change the splicing efficiency, which resulted in the change of amino acid coding and eventually affected the biological traits [38,39]. Even if the intron mutation has no effect on the amino acid sequence, it may also result in the inactivation of the splicing site, or it may contain enhancer sequences to promote the specific transcription of the gene, affecting the animal phenotype [40,41]. The correlation between the SNPs on the introns and the milk fat traits of cattleyak may have a causal mutation, or it may be that these five SNPs are closely related to the SNPs on the exons. The exact cause needs further functional verification in a future study.

The effects of a specific gene on biological traits might be related to a combination of SNPs in that gene [42]. This study focuses on the genotype combination of SNPs causing amino acid changes. It was found that three SNPs (g.6256 C > T, g.24791 A > G, g.29121 $A>G$ ) caused amino acids changes and we obtained three haplotypes (Figure S1). Based on these three haplotypes, four combinations were obtained. The amino acids of the three SNPs in H1-H1 were changed compared with the standard sequence. Moreover, the milk fat content and fatty acid content of the $\mathrm{H} 1-\mathrm{H} 1$ population were significantly higher than those of other diplotypes. The milk fat content and fatty acid content of the $\mathrm{H} 2-\mathrm{H} 2$ population without amino acid mutation was the lowest. Therefore, it is clear that the mutation of amino acids has a positive effect on the percentage of milk fat and the content of fatty acids.

\section{Conclusions}

In conclusion, nine SNPs were detected in the CDS and their adjacent non-coding regions of the SORBS1 gene of the cattleyak, and all of these SNPs had a significant correlation with their milk fat traits. Additionally, H1-H1 (CCAAAA) is the dominant diplotype significantly related to the milk fat traits of cattleyak. These sites provide new molecular markers and a theoretical basis for the screening of the milk fat traits of cattleyak.

Supplementary Materials: The following are available online at https://www.mdpi.com/article/ 10.3390 /ani11123461/s1. Figure S1. The mutation of SNPs caused the change of amino acid sequence (red maker).

Author Contributions: Experiment design, L.Y. and X.X.; collection of blood samples, L.Y., X.M. and Y.H.; software, X.M. and H.Y.; formal analysis, L.Y. and M.Y.; writing —original draft preparation, L.Y.; writing - review and editing, X.X., Y.Z. and J.L. All authors have read and agreed to the published version of the manuscript.

Funding: This research was funded by the Science and Technology Department of Sichuan province Key R and D Program (grant No. 2021YFN0121), the Fund of China Scholarship Council (No. 202008510085) and the Fundamental Research Funds for the Central Universities of Southwest Minzu University (grant No. 2021PTJS20).

Institutional Review Board Statement: The experimental animals and operating procedures in this study obeyed the policies of the national and local animal welfare agencies, and they were approved by the Animal Care and Use Committee of Southwest Minzu University and performed in accordance with animal welfare and ethics. 
Data Availability Statement: No new data were created or analyzed in this study. Data sharing is not applicable to this article.

Conflicts of Interest: No conflict of interest exists in the submission of this manuscript, and the manuscript is approved by all authors for publication.

\section{References}

1. Zi, X.D. Reproduction in female yaks (Bos grunniens) and opportunities for improvement. Theriogenology 2003, 59, 1303-1312. [CrossRef]

2. Barsila, S.R.; Devkota, N.R.; Kreuzer, M.; Marquardt, S. Effects of different stocking densities on performance and activity of cattle $\times$ yak hybrids along a transhumance route in the Eastern Himalaya. Springerplus 2015, 4, 398. [CrossRef]

3. Shah, M.A.; Xu, C.; Wu, S.; Zhao, W.; Luo, H.; Yi, C.; Liu, W.; Cai, X. Isolation and characterization of spermatogenic cells from cattle, yak and cattleyak. Anim. Reprod. Sci. 2018, 193, 182-190. [CrossRef]

4. Filipczak-Fiutak, M.; Pluta-Kubica, A.; Domagała, J.; Duda, I.; Migdał, W. Nutritional value and organoleptic assessment of traditionally smoked cheeses made from goat, sheep and cow's milk. PLoS ONE 2021, 16, e0254431. [CrossRef]

5. Park, C.H.; Ranaraja, U.; Dang, C.G.; Kim, J.J.; Do, C.H. Genetic parameters for milk fatty acid composition of Holstein in Korea. Asian-Australas. J. Anim. Sci. 2020, 33, 1573-1578. [CrossRef]

6. $\quad$ Liang, Y.; Gao, Q.; Zhang, Q.; Arbab, A.; Li, M.; Yang, Z.; Karrow, N.A.; Mao, Y. Polymorphisms of the ACSL1 Gene Influence Milk Production Traits and Somatic Cell Score in Chinese Holstein Cows. Animals 2020, 10, 2282. [CrossRef]

7. Sanchez, M.P.; Ferrand, M.; Gelé, M.; Pourchet, D.; Miranda, G.; Martin, P.; Brochard, M.; Boichard, D. Short communication: Genetic parameters for milk protein composition predicted using mid-infrared spectroscopy in the French Montbéliarde, Normande, and Holstein dairy cattle breeds. J. Dairy Sci. 2017, 100, 6371-6375. [CrossRef]

8. Prakapenka, D.; Liang, Z.; Jiang, J.; Ma, L.; Da, Y. A Large-Scale Genome-Wide Association Study of Epistasis Effects of Production Traits and Daughter Pregnancy Rate in U.S. Holstein Cattle. Genes 2021, 12, 1089. [CrossRef]

9. Sun, X.; Liang, Y.; Gao, Q.; Guo, J.; Tang, C.; Shi, K.; Yang, Z.; Mao, Y. AGPAT3 Gene polymorphisms are associated with milk production traits in Chinese Holstein cows. J. Dairy Res. 2021, 15, 1-6. [CrossRef]

10. Brzáková, M.; Rychtářová, J.; Čítek, J.; Sztankóová, Z. A Candidate Gene Association Study for Economically Important Traits in Czech Dairy Goat Breeds. Animals 2021, 11, 1796. [CrossRef]

11. Yang, F.; Zhang, M.; Rong, Y.; Liu, Z.; Yang, S.; Zhang, W.; Li, J.; Cai, Y. A Novel SNPs in Alpha-Lactalbumin Gene Effects on Lactation Traits in Chinese Holstein Dairy Cows. Animals 2019, 10, 60. [CrossRef]

12. Pegolo, S.; Mota, L.; Bisutti, V.; Martinez-Castillero, M.; Giannuzzi, D.; Gallo, L.; Schiavon, S.; Tagliapietra, F.; Revello Chion, A.; Trevisi, E.; et al. Genetic parameters of differential somatic cell count, milk composition, and cheese-making traits measured and predicted using spectral data in Holstein cows. J. Dairy Sci. 2021, 104, 10934-10949. [CrossRef]

13. Stoop, W.M.; van Arendonk, J.A.; Heck, J.M.; van Valenberg, H.J.; Bovenhuis, H. Genetic parameters for major milk fatty acids and milk production traits of Dutch Holstein-Friesians. J. Dairy Sci. 2008, 91, 385-394. [CrossRef]

14. Naserkheil, M.; Miraie-Ashtiani, S.R.; Sadeghi, M.; Nejati-Javaremi, A.; Park, C.W.; Min, K.S.; Lee, D. Exploring novel single nucleotide polymorphisms and haplotypes of the diacylglycerol O-acyltransferase 1 (DGAT1) gene and their effects on protein structure in Iranian buffalo. Genes Genom. 2019, 41, 1265-1271. [CrossRef]

15. Schennink, A.; Heck, J.M.; Bovenhuis, H.; Visker, M.H.; van Valenberg, H.J.; van Arendonk, J.A. Milk fatty acid unsaturation: Genetic parameters and effects of stearoyl-CoA desaturase (SCD1) and acyl CoA: Diacylglycerol acyltransferase 1 (DGAT1). J. Dairy Sci. 2008, 91, 2135-2143. [CrossRef]

16. Schennink, A.; Stoop, W.M.; Visker, M.H.; van der Poel, J.J.; Bovenhuis, H.; van Arendonk, J.A. Short communication: Genomewide scan for bovine milk-fat composition. II. Quantitative trait loci for long-chain fatty acids. J. Dairy Sci. 2009, 92, $4676-4682$. [CrossRef] [PubMed]

17. Chang, T.J.; Wang, W.C.; Hsiung, C.A.; He, C.T.; Lin, M.W.; Sheu, W.H.; Chang, Y.C.; Quertermous, T.; Chen, I.; Rotter, J.; et al. Genetic variation in the human SORBS1 gene is associated with blood pressure regulation and age at onset of hypertension: A SAPPHIRe Cohort Study. Medicine 2016, 95, e2970. [CrossRef]

18. Chang, T.J.; Wang, W.C.; Hsiung, C.A.; He, C.T.; Lin, M.W.; Sheu, W.H.; Chang, Y.C.; Quertermous, T.; Chen, Y.I.; Rotter, J.I.; et al. Genetic variation of SORBS1 gene is associated with glucose homeostasis and age at onset of diabetes: A SAPPHIRe Cohort Study. Sci. Rep. 2018, 8, 10574. [CrossRef]

19. Germain, M.; Pezzolesi, M.G.; Sandholm, N.; McKnight, A.J.; Susztak, K.; Lajer, M.; Forsblom, C.; Marre, M.; Parving, H.H.; Rossing, P.; et al. SORBS1 gene, a new candidate for diabetic nephropathy: Results from a multi-stage genome-wide association study in patients with type 1 diabetes. Diabetologia 2015, 58, 543-548. [CrossRef]

20. Irvin, M.R.; Zhi, D.; Aslibekyan, S.; Claas, S.A.; Absher, D.M.; Ordovas, J.M.; Tiwari, H.K.; Watkins, S.; Arnett, D.K. Genomics of post-prandial lipidomic phenotypes in the Genetics of Lipid lowering Drugs and Diet Network (GOLDN) study. PLoS ONE. 2014, 9, e99509. [CrossRef]

21. Baumann, C.A.; Ribon, V.; Kanzaki, M.; Thurmond, D.C.; Mora, S.; Shigematsu, S.; Bickel, P.E.; Pessin, J.E.; Saltiel, A.R. CAP defines a second signalling pathway required for insulin-stimulated glucose transport. Nature 2000, 407, 202-207. [CrossRef] 
22. Lin, W.H.; Chiu, K.C.; Chang, H.M.; Lee, K.C.; Tai, T.Y.; Chuang, L.M. Molecular scanning of the human sorbin and SH3-domaincontaining-1 (SORBS1) gene: Positive association of the T228A polymorphism with obesity and type 2 diabetes. Hum. Mol. Genet. 2001, 10, 1753-1760. [CrossRef] [PubMed]

23. Cho, W.C.; Jang, J.E.; Kim, K.H.; Yoo, B.C.; Ku, J.L. SORBS1 serves a metastatic role via suppression of AHNAK in colorectal cancer cell lines. Int. J. Oncol. 2020, 56, 1140-1151. [CrossRef] [PubMed]

24. Li, C.; Sun, D.; Zhang, S.; Wang, S.; Wu, X.; Zhang, Q.; Liu, L.; Li, Y.; Qiao, L. Genome wide association study identifies 20 novel promising genes associated with milk fatty acid traits in Chinese Holstein. PLoS ONE 2014, 9, e96186.

25. Cao, M.; Shi, L.; Peng, P.; Han, B.; Liu, L.; Lv, X.; Ma, Z.; Zhang, S.; Sun, D. Determination of genetic effects and functional SNPs of bovine HTR1B gene on milk fatty acid traits. BMC Genom. 2021, 22, 575. [CrossRef]

26. Singh, A.; Kumar, A.; Gondro, C.; da Silva Romero, A.R.; Karthikeyan, A.; Mehrotra, A.; Pandey, A.K.; Dutt, T.; Mishra, B.P. Identification of genes affecting milk fat and fatty acid composition in Vrindavani crossbred cattle using 50 K SNP-Chip. Trop. Anim. Health Prod. 2021, 53, 347. [CrossRef]

27. Zwierzchowski, L.; Ostrowska, M.; Żelazowska, B. Bagnicka, E. Single nucleotide polymorphisms in the bovine SLC2A12 and SLC5A1 glucose transporter genes-The effect on gene expression and milk traits of Holstein Friesian cows. Anim. Biotechnol. 2021, 6, 1-11. [CrossRef]

28. Bordonaro, S.; Tumino, S.; Marletta, D.; De Angelis, A.; Di Paola, F.; Avondo, M.; Valenti, B. Effect of GH p.L127V Polymorphism and Feeding Systems on Milk Production Traits and Fatty Acid Composition in Modicana Cows. Animals 2020, 10, 1651. [CrossRef]

29. Labonté, M.Ė.; Jenkins, D.J.; Lewis, G.F.; Chiavaroli, L.; Wong, J.M.; Kendall, C.W.; Hogue, J.C.; Couture, P.; Lamarche, B. Adding MUFA to a dietary portfolio of cholesterol-lowering foods reduces apoAI fractional catabolic rate in subjects with dyslipidaemia. Br. J. Nutr. 2013, 110, 426-436. [CrossRef]

30. Golanski, J.; Szymanska, P.; Rozalski, M. Effects of Omega-3 polyunsaturated fatty acids and their metabolites on haemostasiscurrent perspectives in cardiovascular disease. Int. J. Mol. Sci. 2021, 22, 2394. [CrossRef]

31. Mäki-Tanila, A.; Webster, L. Heritability, SNP, inbreeding, dairy cattle, genomic selection-and other keywords. J. Anim. Breed. Genet. 2019, 136, 1-2. [CrossRef] [PubMed]

32. Azimu, W.; Manatbay, B.; Li, Y.; Kaimaerdan, D.; Wang, H.E.; Reheman, A.; Muhatai, G. Genetic diversity and population structure analysis of eight local chicken breeds of Southern Xinjiang. Br. Poult. Sci. 2018, 59, 629-635. [CrossRef]

33. Santos, C.P.; Aguiar, A.F.; Giometti, I.C.; Mariano, T.B.; de Freitas, C.; Nai, G.A.; de Freitas, S.Z.; Pai-Silva, M.D.; Pacagnelli, F.L. High final energy of gallium arsenide laser increases MyoD gene expression during the intermediate phase of muscle regeneration after cryoinjury in rats. Lasers Med. Sci. 2018, 33, 843-850. [CrossRef]

34. Huang, Y.Z.; He, H.; Sun, J.J.; Wang, J.; Li, Z.J.; Lan, X.Y.; Lei, C.Z.; Zhang, C.L.; Zhang, E.P.; Wang, J.Q.; et al. Haplotype combination of SREBP-1c gene sequence variants is associated with growth traits in cattle. Genome 2011, 54, 507-516. [CrossRef] [PubMed]

35. He, X.; Zhang, Z.; Chu, M. The effect of SNP rs400827589 in exon 2 of the MTNR1B gene on reproductive seasonality and litter size in sheep. Vet. Med. Sci. 2020, 6, 804-812. [CrossRef]

36. Jones, M.; Sergeant, C.; Richardson, M.; Groth, D.; Brooks, S.; Munyard, K. A non-synonymous SNP in exon 3 of the KIT gene is responsible for the classic grey phenotype in alpacas (Vicugna pacos). Anim. Genet. 2019, 50, 493-500. [CrossRef]

37. Mesrian Tanha, H.; Rahgozar, S.; Mojtabavi Naeini, M. ABCC4 functional SNP in the $3^{\prime}$ splice acceptor site of exon 8 (G912T) is associated with unfavorable clinical outcome in children with acute lymphoblastic leukemia. Cancer Chemother. Pharmacol. 2017, 80, 109-117. [CrossRef]

38. Xiang, G.; Ren, J.; Hai, T.; Fu, R.; Yu, D.; Wang, J.; Li, W.; Wang, H.; Zhou, Q. Editing porcine IGF2 regulatory element improved meat production in Chinese Bama pigs. Cell. Mol. Life Sci. 2018, 75, 4619-4628. [CrossRef]

39. Yadav, T.; Magotra, A.; Bangar, Y.C.; Kumar, R.; Yadav, A.S.; Garg, A.R.; Bahurupi, P.; Kumar, P. Effect of BsaA I genotyped intronic SNP of leptin gene on production and reproduction traits in Indian dairy cattle. Anim. Biotechnol. 2021, 9, 1-7. [CrossRef] [PubMed]

40. Mi, T.; Liu, K.; Guo, T.; Li, L.; Wang, Y.; Li, C.; Cui, Y.; Dai, J.; Zhang, Y.; Hu, S. Analysis of the eighth intron polymorphism of NR6A1 gene in sheep and its correlation with lumbar spine number. Anim. Biotechnol. 2021, 4, 1-7. [CrossRef]

41. Nair, V.; Sankaranarayanan, R.; Vasavada, A.R. Deciphering the association of intronic single nucleotide polymorphisms of crystallin gene family with congenital cataract. Indian J. Ophthalmol. 2021, 69, 2064-2070. [PubMed]

42. Magotra, A.; Gupta, I.D.; Ahmad, T.; Alex, R. Polymorphism in DNA repair gene BRCA1 associated with clinical mastitis and production traits in indigenous dairy cattle. Res. Vet. Sci. 2020, 133, 194-201. [CrossRef] [PubMed] 